\title{
As I see it: enclosing identity
}

\author{
Ian Angell
}

Received: 6 April 2008 / Accepted: 5 June 2008 / Published online: 18 December 2008

(C) Identity Journal Limited 2008

\begin{abstract}
This article claims that an 'enclosure of the commons' is underway, which reaches far beyond intellectual property, to a point where, through profiling, 'identity' has itself become enclosed property that can be owned by another. With a detour through the natures of both money and innovation, this paper looks at the imperative driving 'intellectual property rights.' By introducing the notion of biopiracy, it shows how 'invasion of privacy' is justified, and ends with "a world of rapacious, state-aided 'privatization"” of enclosed identity: the ultimate identity theft.
\end{abstract}

Keywords Biopiracy · Commons · Debt · Enclosure - Identity theft · Innovation · Money $\cdot$ Privacy $\cdot$ Property rights
Abbreviations
CCC Chaos Computer Club
DRM Digital Rights Management
DVLA Driver and Vehicle Licensing Agency
ICT Information and Communication Technology
IPR Intellectual Property Rights
RFID Radio Frequency Identification
UDHR Universal Declaration of Human Rights
WIPO World Intellectual Property Organisation
DVLA Driver and Vehicle Licensing Agency

\section{Introduction}

In his seminal article 'The Second Enclosure Movement', James Boyle (2003) warned of the "enclosure of the intangible commons of the mind." He gave an 
analysis of Intellectual Property Rights (IPR) in which he described "a world of rapacious, state-aided 'privatization,' a conversion into private property of something that had formerly been common property or, perhaps, had been outside of the property system altogether." Although agreeing wholeheartedly with Boyle's conclusions on IPR, this paper considers 'enclosure of the commons' not as a discrete Movement, but as a universal social dynamic in the tension between the 'individual and the collective.' In this dynamic, certain non-productive properties will be returned to the commons, whereas some such properties and parts of the commons will be re-enclosed whenever new socio-economic conditions point to innovative proprietary opportunities. This article claims that the scope of such enclosure goes way beyond intellectual property, striking at the very core of personal identity. To support this assertion the reader is taken along the continuum from the notion of common property, through the enclosure of property in general, to intellectual property, and ending with a claim that 'identity' itself has become property.

Until very recently identity was "outside of the property system altogether," however, that status is now under a concerted two-pronged attack. Every national government has always claimed the need to identify its citizens unambiguously for administrative and security purposes. Meanwhile, business, in its zeal to market products, has resorted to profiling potential customers. Hence a joint political and commercial imperative has arisen that calls for an individual's physical and behavioural attributes to be 'sampled' scientifically in such a way that the data can be used to identify that individual uniquely.

Each sample is described, and then represented in some externalised/accessible form (a mix of textual, numerical and biometric data). These proxies for identity are stored in a database for subsequent 'identity management,' all masquerading as that individual's private property. Such social/commercial databases have been evolving slowly over the years; companies have come late into the fray, but states have been collecting 'census' data for millennia! However, that evolution is now accelerating with the functionality delivered by information and communication technologies (ICTs).

This imperative is gradually taking away the individuals' common right to their own identity, even to ownership of their own body parts - see below (Wald 2005; WIPO 2006.) We tend to think of identity as private property, as belonging to us, that it is us - but we'd be wrong. The moment our identity is sampled it starts being treated as property, separate from us. To understand this separation it is crucial to distinguish between identity and the way it is represented. What is this stored identity? Not identity as such, but a mere shadow representation of the social, biometric and behavioural properties of each individual: a proxy that has been captured by whoever owns the database. Once enclosed, the proxy is turned into property, and rented back to that individual to be used as proof of identity. Paradoxically, at the same time as the individual's 'identity' is being enclosed, in some senses it is also becoming common property - accessible to anyone who can gain entry (legal or otherwise) to the database.

If that database attains quasi-legal status then established social institutions will allow 'sampled' individuals access to their personal property and/or social benefits only with the expressed permission of the database. That is, each real identity has to submit itself to the database to prove itself similar enough to its proxy. Thus, the entry of an individual's data in the database restricts that individual's freedom of 
action. Subsequently, various other forms of data on the individual are appended to the database, not only for administrative convenience, but also for its incomegenerating potential for the database owner and others. There are a number of very good commercial reasons for businesses to use this extendable database, and any administration costs (actually 'costs plus') will of course be passed back onto the sampled individuals in the form of charges made for the utility of this 'proof of identity.' In this way identity is placed in the public domain, or at the very least in the commercial domain, and will be accessible to all ... at a price!

Paradoxically, individuals volunteer more and more of their personal data to these databases for the promise of protection against so-called 'identity theft,' only to find themselves at an increased risk. What is mistakenly called 'identity theft,' which is the theft of access to a proxy stored in this database 'one stop shop,' is so much easier than holding a person to ransom, since only the key to the proxy database needs to be captured to allow others access to that person's assets.

\section{Enclosing the 'commons'}

This article claims that this whole debate over identity revolves around the notion of property. The metaphor/theory being used, namely the enclosure of the commons, originated in England and Wales with Common Land, namely a tract of land owned by one person, but over which other people (the commoners) may exercise certain traditional rights. Nowadays, 'commons' has come to mean resources that a community recognizes as being accessible to its members, including to a certain extent the right to use private property as well as natural resources. It is also understood that if and when a property right expires, then the property returns to the commons. Note it is deemed appropriate here to distinguish between state ownership (by government) and ownership by everybody (the commoners.)

Both commons and private/state property can co-exist quite peacefully for a while, because of compromises worked out over time, usually because the commoners were taking value from what the owners thought worthless, or when no clear owner can be found. However, problems arise whenever social, economic or technological innovations disrupt the status quo of the value system.

Then a transfer of resources from the commons to purely private or state ownership occurs: what is known generally as Enclosure - or as Inclosure in the British legal system. The Inclosure Acts in England, mostly from the mid-eighteenth to the mid-nineteenth centuries, enclosed large areas of the better common land. By the present century, the only remaining commons are a few pastures, village greens, and public rights of way. In today's Britain it is rights of way that comprise the frontline of the on-going war over enclosures, namely the battle between ramblers and farmers, the latter claiming that the former are trespassing on their land and thereby disrupting agricultural production.

This is typical of the economic arguments used to justify enclosures, which revolve around two issues: either the common land is being underproductive, or the 'fact' that the commons is a renewable asset, which requires active and responsible usage to remain viable and to prevent the so-called tragedy of the commons (Hardin, 1968.) The tragedy occurs when, through neglect, overuse, or abuse, the resource 
becomes degraded. This was the case in England between the fourteenth and sixteenth centuries, when the population had declined through plague and a slow drift of tenants to the towns, leaving agricultural land in poor condition. With their wealth under threat, landowners argued that they were forced into more efficient practices (that was their moral and economic justification anyway), whence the solution of choice - enclosure, to facilitate sheep herding. The need for far fewer labourers than in arable farming soon led to unemployment and displacement of rural poor; the loss of grain production also resulted in intermittent famines. On the plus side, enclosure meant stock was segregated into separate herds, enabling selective breeding and a reduction in the spread of animal diseases.

Before the reign of 'Good Queen Bess' (Elizabeth I), 1558-1603, the British monarchy was generally opposed to the practice: it introduced anti-enclosure Acts to stop the loss of available arable farmland. This was not altruism on its part. The Crown was more concerned about lower tax revenues, fewer potential conscripts for the army, and the rise of a disaffected and unruly, possibly rebellious underclass.

By the eighteenth century, the notion of a "common wealth" of agricultural communities had been displaced by the Wealth of Nations, a la Adam Smith (1776.) The market economy was emerging: the economic aim was no longer subsistence from agriculture, rather a marketable surplus from both farming and increasingly industry. As a consequence of the enclosure of common land, the landowners became rich, and many ordinary people were made destitute. The practice was widely condemned as a huge swindle on the commoners, driving many of the newly impoverished to a life of violence and crime, as is clear in this snippet of an eighteenth century poem (quoted in full in the Boyle paper):

They hang the man, and flog the woman,

That steals the goose from off the common;

But let the greater villain loose,

That steals the common from the goose.

The legal position in the UK concerning common land remains very confused and confusing, and many ambiguities, inconsistencies and irregularities remain.

But does the notion of commons have any general relevance today? Of course! When lending books, records, artworks to friends; or even selling them second hand; or giving them away as gifts, not to mention using 'identity,' we are entering a commons. What is this but commoners exercising traditional rights over certain aspects of what is actually other people's property? What is Digital Rights Management (DRM), in an attempt to prevent wholesale downloading of music and films from the Internet, but "enclosure of the intangible commons of the mind?"

\section{Government, money and self-referential systems}

Why then do, governments (even democratic ones) support such enclosures, preferring to enrich a few individuals and companies, rather than share the largesse with the many? Cynics, like Professor Kenneth Minogue (1995), would say it is self-interest: the 
purpose of every government is to raise money, to pay for government - a classic self-referential system. However, this is only partly the case. The raising of money is made possible by institutionalising (another less obvious word for enclosing) 'property.' The commonly perceived notion of 'personal property' is of 'things belonging to someone.' However, for a long while this somewhat naïve view has been superseded by a far more pertinent definition: property is a government-sanctioned monopoly right over an enclosure, which is legally enforced through their courts.

Government, and government alone, claim the right to signify ownership — but at a price. They will bestow rights of ownership on those groups that generate the maximum revenue for the state - government will seize (enclose) under-producing property and transfer it to those who promise productivity. Whatever the pretence, this has nothing to do with what is popularly understood to be the moral justification of property owning.

'Ownership rights,' therefore, are rented from the state, to be paid for, which means some of these assets, or rather the government-guaranteed rights over the assets, must be made productive; namely turned into property, monetized, and subsequently rented or sold - either way, new debt is incurred somewhere in the economic system.

Government can seize (enclose) these assets through the courts at any time, simply by passing laws claiming ownership for itself, before possibly transferring it to others - at a price. However, the government cannot behave arbitrarily, because excessive seizure will limit the willingness of individuals to turn their assets into property, undermining the viability of the whole system - a harsh lesson that is eventually learned by every socialist state.

When paying the required price, rendering "unto Caesar the things which are Caesar's" (as recommended in Matthew 22:21), the normal assumption is that government money is being used, namely the notes and coins that the government prints and mints. But that would be wrong. Most of the money supply is actually created by the population itself, over and above the government float: that float being a mortgage on state-owned property and future taxation.

In England a $£ 50$ bank note states that the Bank of England promises to pay the bearer $£ 50$ on demand. When a customer goes into an English bank and demands $£ 50$, what is she given? Another note with the same promise - just a piece of paper. What an amazing alchemy, only in this case it is paper and not lead that is being transmuted into gold!

The real magic, however, lies elsewhere. The vast majority of money does not exist as the notes and coins of the government float, rather as imaginary numbers that the government-backed Fractional Reserve System allows to be written into a bank ledger. Every time a loan is taken out, the bank — which, by the way, doesn't need to have all the money requested - simply magicks that money into existence. All it needs is the customer's promise to repay, and it has government-backed threats to ensure that the customer does repay, and with interest.

This is not some form of conspiracy between the banks and government - rather a paradox. It is a systemic consequence of the way that money operates: money is a promise to repay a debt, with money! The beauty of this self-referential system (that is both money and property) is that no one is in control; everyone involved is trapped, sleepwalking through an explosion of peculiar emergent economic and 
social effects. Simultaneously, we are all ambiguously both commoners and stakeholders (to a greater or lesser extent) in money and property, and in the latter role most of us have a vested interest in keeping the system going. From this position, government may be seen as an emergent homeostatic sub-system, necessary for maintaining the continuity of the system.

The system itself is in a permanent state of unstable equilibrium. However, if too many customers demand that their ledger entries are returned in cash, in the form of those pieces of paper, a 'run' on the bank will result, and the magic collapses. A bank can also collapse when too many people default on their loans. Both situations occurred in the winter of 2007/2008 when problems with US sub-prime mortgages triggered the financial woes of Northern Rock Building Society, Bear Stearns, Lehman Brothers, AIG and many other institutions worldwide.

Only blind confidence (and not a little ignorance) keeps this whole self-referential anti-gravity cash machine from crashing to earth. The whole process stays aloft because of the time-lag between borrowing and repayment (in full, plus interest.) But repayment requires the creation of brand new money in that interim, in order to pay the interest over and above inflation. This must lead to an exponentially increasing demand for money, that itself needs an increased scale of indebtedness. Unfortunately, the symbiosis between government, banks, and major 'rentiers' is not enough keep the show on the road - it needs a perpetual supply of new energy (new debt) to keep the implicit exponential growth going. The monetisation of real estate, raw materials, food, and labour (and its products) can only go so far. Beyond this, new assets have to be created within the human value system.

\section{New money for old}

Unfortunately, there is a serpent in this economic Garden of Eden. Enclosure creates an artificially closed economic system that cannot remain homeostatic indefinitely. It requires the input of new energy (new enclosures that become debt) to avoid the decline into entropic death - hence the need both for creating new property, and reenclosing unproductive old property, thereby reviving it. There can never be enough old money around to fund the requisite exponential growth, even when inflation is taken into account, and so the government must always be on the lookout for innovators and entrepreneurs that can facilitate the creation of new inventions to be enclosed in order to generate an infusion of new debt, and hence new money.

The wishes of the two groups, old and new money, are often in conflict, with government acting as arbiter. The basis of that arbitration is not fairness or morality, but the rents that each group can offer to the state's money supply. With the property behind old money often already leveraged to its limit, government must eventually renege on its partnership with old money, and deal with the newcomers, who can offer a better deal.

For example, by the early nineteenth century, landowners were the UK government's 'rentiers' of choice, but a new and more powerful group was in the ascendancy: the industrialists. The turning point of that particular battle came in 1846 in England with the Repeal of the Corn Laws. The Corn Laws were import tariffs introduced in 1804 to protect English corn growers from cheap foreign 
imports. Industrialists and the urban middle-classes had to pay higher wages just so their workers could afford to buy bread. The state was in effect subsidizing the landowners with industrialists' money.

Whatever the deals, ultimately the state's money supply depends on the total debt incurred when purchasing or renting various property rights within its jurisdiction, which is why the state must guarantee that the majority of debtors repay their debts. This it achieves by intimidating debtors with the threat of legal action, and for which it rakes off its cut in this extortion racket. The more assets that can be turned into property, the greater the debt, the greater the supply of money.

\section{"The intangible commons of the mind"}

It was only a matter of time before intellectual and other virtual assets joined the physical as property, so that so-called intellectual property could be monetized and added to the debt mountain, all for the benefit of the state's money supply. Of course this requires moral justification and economic arguments to disguise the loss of the longstanding rights of both commoners and the owners of underperforming properties.

Most of today's legislation on intellectual property cites two forms of justification. First, the creators of new works/inventions have a moral right to ownership. Second, society as a whole benefits with the promotion of innovation and the creation of new works.

The 1948 Universal Declaration of Human Rights (UDHR), Article 27.2 states that "everyone has the right to the protection of the moral and material interests resulting from any scientific, literary or artistic production of which he is the author." This follows on directly from the seemingly contradictory Article 27.1: "everyone has the right freely to participate in the cultural life of the community, to enjoy the arts and to share in scientific advancement and its benefits." In 1967 the UN World Intellectual Property Organization (WIPO) was set up "to encourage creative activity, [and] to promote the protection of intellectual property throughout the world" by introducing new forms of enclosure - arguably they achieved the exact opposite.

However, none of the above justification is self-evident. Thomas Jefferson thought that ideas should be spread freely for the good of mankind. It is arguable that Science, which according to Article 27.1 should be shared, would never have developed under an IPR regime. Some scientists have become so concerned that Science is becoming enclosed in a sea of IPRs that they have launched the Science Commons initiative (see http://www.sciencecommons.org) in an attempt to break down the growing barriers to research. They seek "open access to scholarly literature and data, and are intent on identifying and easing key barriers to the movement of information, tools and data throughout the scientific research cycle. The hope is to combine their publishing, data, and licensing approaches, in order to develop solutions for a truly integrated and streamlined research process."

"Shortly after a large-scale clinical trial in 1955, the first inactivated polio vaccine was being injected into tens of millions of people around the world - possibly the most successful pharmaceutical product launch in history. Asked why he had not obtained a patent on the phenomenally successful vaccine, Jonas Salk reportedly 
replied, 'That would be like patenting the sun.' A few decades later, this view seemed laughably quaint." (Dove 2002.)

Intellectual Property Rights prohibit rather than permit. This may lead to what some would label a government-condoned anti-Trust, anti-competitive situation where a cartel of favoured users may be given an unfair advantage. People without permission, and who want to adapt a work, are barred from, or are at a disadvantage when doing so.

Yet most innovations are derivative applications that spring from a prior innovation, exactly as Herbert Kroemer, the 2000 Nobel Physics Laureate, explains in Kroemer's Lemma of New Technology: "The principal applications of any sufficiently new and innovative technology always have been — and will continue to be - applications created by that technology." (see Stefik \& Stefik 2006) The same can be said of innovation in general. And those applications are innovated not by the developments by the original creator, but by users at the margins, unfettered by organisational and institutions constraints, who are free to have radical ideas. Ecommerce, as we know it today, was created by consumers who saw business opportunities, and not by the main technology players of the time. This was the case for Amazon, Google, Facebook, Skype and many others in today's list of large companies.

What Kroemer is implying is that although a technological innovation occurs in a particular context, numerous people will run with that innovation to create a whole raft of derivative applications that could not even be imagined by the original inventor. If that inventor restricts what can be done with his work, in effect banning derivative works, then he is limiting its potential, and cutting off all future revenue streams.

In general there is no requirement for the rights-holders to exploit their property, which means development of certain innovations can be blocked: holders of old technology buy up the new patents so they can kill off research, and continue profiting from their old patents. That is why some countries require that the invention be exploited, and threaten to revoke (re-enclose) the patent rights, awarding a license to others wishing to exploit the patented invention.

The operating strategy of some holding companies, known as "patent trolls," is to collect an IPR portfolio, and then sue all and sundry for infringements, while doing little to develop the inventions themselves. In essence they have created a monopsony among developers: a market where there is only one purchaser - themselves.

Furthermore, rights to just one single artefact may require permission from every one of a whole bundle of property rights. According to Heller and Eisenberg (1998), intellectual property rights may become so fragmented that, effectively, no one can take advantage of them, because it becomes impossible to track down all the holders. Mercer and Kinsella (2001) go further to argue that IPR "are a burden to marketplace transactions, and discourage business startups."

\section{The rise and rise of IPR}

Despite all the problems, the growing relevance of IPR to the economy is undeniable, as is the increasing determination with which rights are being enforced. Most of the recent debate has focused on the negative impact that 'piracy' on the Internet is having on the earning power of the owners of copyright. Indeed, some say that the Net has ushered in a whole new tragedy of the commons. Without the need 
of a physical medium, a work can now be dematerialised, copied, shared, and given away ad nauseum. The owners of copyright claim to have suffered serious financial loss due to the subsequent wholesale downloading of pirated digital files. Rightsholders have gone to government for protection and recompense, demanding new legal forms of enclosure for their property to prevent it from being exploited as freely as a commons.

One response, Digital Rights Management (DRM), can be seen clearly as enclosure. The common rights about recording, sharing and manipulating music, which the record buying public have taken for granted for decades, are now being eroded. We have the ludicrous situation where those who naively have legally bought music and movies, have their usage severly constrained: they can neither share it, nor sell it on — not even take it to another 'region;' their PCs are being externally searched; limits are placed on the number of devices on which users can play music they have bought legally. Privacy as a common right is being enclosed. Meanwhile those with pirated CDs/DVDs can do what they like - although they do face the full force of the law in the highly unlikely event of being caught.

To see how much the world has changed it is apposite to consider a story told by Cory Doctorow (2007), the digital activist. He was visiting the National Portrait Gallery in London to see an exhibition of Pop Art Portraits, with works on display by Larry Poons, Eduardo Paolozzi, Robert Rauschenberg, Andy Warhol, Peter Blake, Ray Johnson, Roy Lichtenstein etc. There were collages galore! Many of those images were created by transforming the works of others "to make statements and evoke emotions never countenanced by the original creators." In other words, the greats of Pop Art from the 1960s believed in free expression, and used their art to justify their freedom to ignore any rights implicit in the original source material.

And yet when Cory tried to photograph some of the art, he was stopped ... because (and don't laugh) he was infringing the copyright of the artists! He wasn't even allowed to photograph the "No Flash Photography" sign ... because the typography and layout of the signs were also copyrighted. How the world has changed. It's very doubtful if today Warhol et al would get away with using unlicensed images of Elvis, or Mickey Mouse, or cans of Campbell's soup. For nowadays copyright is everywhere. Companies in pursuit of 'branding,' use their logos on all sorts of objects, so that the image goes way beyond a trade mark, and hence the old legal defence no longer holds, namely that because the image was being used on a work of art, it couldn't be confused with the original commercial product.

Those who insist on securely enclosed property fail to see that it is perfectly feasible for common assets to be used in the creation of secondary 'service' markets (for example Red Hat), which in the long run can induce even more sales/debt than the old primary property system. Furthermore, the fact of entropy means that the old system itself will only continue if it is regularly boosted by the negentropy of new ideas. Following Kroemer's insight, the trick is to collect payment from the creators of derivative works as their market is taking off — not try to strangle them at birth, and having failed at that, to treat them as pirates.

To date history has kept on repeating itself: today's respectable businesses were yesterday's pirates. The sheet music industry objected to the phonograph, which grew into a much bigger industry. The phonograph owners originally objected to the 
radio, which helped boost record sales, as well as creating a massive royalty stream. Radio objected to tape recorders. TV and film also objected to video taping - and yet now video raises a substantial proportion of the income of the US movie industry. Furthermore, if the VHS tape had been banned, there would have been no home electronics industry.

In his book, The Pirate's Dilemma, Matt Mason (2008), claims that piracy is a business model that has been used by vigorous economies throughout history. Privateers were there at the birth of the British Empire - India was won by the East India Company, not the British army. According to Mason, the word 'Yankee' derives from the Dutch slang for pirate — 'Janke.' He says Americans shouldn't object to "Chinese piracy" because "this is how America did it." Only degenerate governments think they can legislate against piracy. They may succeed locally, but only at the cost of destroying their economies.

Instead of bleating on about what they are losing through piracy, companies should look for profits in the new markets uncovered by the creativity of those pirates. The alternative is the 'End of History.' Pirates are the future - a government that succeeds in killing them off, kills off its own economic future.

Furthermore, there is a far more sinister consequence to excessive regulation organised crime will move in. Smuggling will prove a bigger problem than piracy. As the owners of film copyrights successfully threaten download websites, the scope for organized gangs to sell cut-price DVDs increases. Owners should not forget that there is a highly effective illegal economy out there, which can only be strengthened with each new raft of intellectual property regulations, and that will cause far more damage to the legal economy than the loss of some film royalties.

The threat of criminalising anyone who dares to 'experiment' with intellectual property, can only end with the rich and the poor anti-capitalists creating derivative works - the rich because they can pay the IPR fees, the poor because they can't. After McDonald's public relations disaster in the "McLibel" case (Vidal 1997), large companies tend to shy away from suing the poor. Most people, however, will be intimidated into the silence of self-censorship. Ideas will no longer be freely expressed because every form of expression will be owned by someone. No one will paint sunflowers because van Gogh's lawyers will have copyrighted 'the idea of painting sunflowers!' What if the 'if then else' clause had been patented. It would have meant no software industry. Impossible? Prevalent attempts to copyright business processes means this nightmare is all too close for comfort; someone has even copyrighted certain yoga techniques, and is demanding royalty payments from people in India.

\section{Biopiracy of body (and mind?)}

Governments may not like it, but they are only too aware of the wealth creating potential of pirates. However the control freaks can't allow everyone that freedom hence the hypocrisy of regulation for the many, and exemption for the preferred few; and governments choose the few! "The law is not meant for Party members." Whether the selected apparatchiks are the most economically effective is a moot point. 
Consequently, the implications of IPR are moving far beyond mere art, entertainment and bodily postures, to the enclosure by others of a person's mind and body: biopiracy made legal, but only for the chosen ones. John Moore from Seattle suffered from hairy-cell leukaemia, and in 1976 had his spleen removed on the recommendation of Dr. David Golde of the University of California Medical Center. Golde and his team subsequently extracted T-lymphocytes from the discarded spleen, and undertook research to establish a cell line, for which Dr. Golde was granted US patent 4438032 in 1984, and from which he generated substantial income (Wald 2005; WIPO 2006.)

Although he had signed the consent form, Moore claimed not to have been fully informed about the commercial potential of the cell line, and so he sued, claiming a share in the patent. The claim was rejected because he was not one of the inventors of the cell line, only the original donor. The court concluded no patient could exercise property rights over discarded body tissues. In giving informed consent (or was it actually uninformed?) Miller had allowed the researchers to enclose his body parts. The court was naturally mindful that extending an individual's property rights to include his organs (perceived as underperforming common assets) would restrict medical research - a justification that would receive popular (that is moral) consent - and so the property was enclosed, and rights given to researchers. If laboratories have to check all the relevant property permissions on each and every sample from the large volume they use, their work would grind to a halt. And anyway, the courts fell back on the legal requirement of informed consent, in that the patient must be told of any financial interests.

The situation gets even more complicated when genetic material is involved, when say a particular gene mutation is shared by a family, or a community. This was the case of the Hagahai people of Papua New Guinea (WIPO 2006.) Researchers discovered that some of the tribe carried a gene that predisposed them to leukaemia but without manifesting any symptoms. Patents were sought from material harvested from a single individual. This raises fascinating issues of whether the consent of a single individual is sufficient when it relates to property that is common to many: enclosing the commons again.

Acutely aware that such biopiracy is rife, in India Professor Anil Gupta realised that the folk-wisdom of India was being usurped by Western (particularly pharmaceutical) companies, and has called for balance and fairness for all. He set up the HoneyBee network within the Society for Research and Initiatives for Sustainable Technologies and Institutions (http:/www.sristi.org), to ensure that the rights of inventive communities were protected. To date he has instigated over twenty 'Shodhyatra' (walks), where groups of volunteer 'scouters' parade through rural villages, inviting the villagers to join in the party atmosphere. The purpose is to inform everyone of the commercial value of indigenous knowledge and local inventions. They help the creator of (say) a new harvesting machine, or the community that has produced an effective health treatment, to enclose and 'own' the rights to their intellectual property. HoneyBee protects the innovators from both the complexities of the patent system, and the administrative processes or their costs, while ensuring that their ideas are not stolen, and that they get the full financial benefit by spreading the inventions globally. 


\section{The ultimate identity theft}

Ownership is at the base of all IPR systems. The maintenance of such systems demands that any act of independence by ordinary people, the commoners, to take freely from the enclosed property (particularly on a global scale), has to be stopped, be it the poaching the proverbial goose, or sharing files from peer-to-peer networks. Given the functionality of modern surveillance technology, property owners, aided by the state, have the capacity to widen their search patterns to check on all unlicensed use of enclosed property, making the process far more efficient and effective.

The goal is 'automatic charging,' and for that each individual must be instantly identifiable, so a bill may be sent to unlicensed users. "They know who you are, and where you live." Big Brother is spying on the innocent and guilty alike, joining George Orwell's Thought Police (Orwell 1949), who have always walked among us masquerading as culture. Technology facilitates the surveillance on a far greater scale. Microsoft, Google, Facebook and who knows what else are "farming" (profiting from enclosing) our every key-stroke. Mobile phones report our exact positions. State-run identity cards are next, after which there will be no escape into anonymity.

No doubt soon we will be convinced of the utility of embedding RFID (Radio Frequency Identification) chips in our bodies, just like we do with our pets. Supposedly it's all for our own benefit. This situation was all foreseen in the Book of Revelations, Chapter 13, verses 16-18.

16. And he causeth all, both small and great, rich and poor, free and bond, to receive a mark in their right hand, or in their foreheads:

17. And that no man might buy or sell, save he that had the mark, or the name of the beast, or the number of his name.

18. Here is wisdom. Let him that hath understanding count the number of the beast: for it is the number of a man; and his number is Six hundred threescore and six.

The state is the beast, conspiring with major commercial interests to enclose everyone's identity. 666 is the Number of the Beast, which spawned countless horror films, although none as horrific as the perpetration of the ultimate identity theft (the theft of the personal commons) that is presently in train.

Whatever the act of enclosure, justification always plays on the ambiguous position of commoner/owner. Enclosure is claimed to minimise loss and/or maximise gain to everyone as private owners in society, but at unfortunate but acceptable costs of reducing access to the commons and invading privacy. The state warns citizens of identity theft by criminals, and then steals their identities itself. What the state calls identity theft is the mere stealing of money and property by means of deception, using stolen identification documents. It plays on immigration fears, saying it intends to prevent outsiders from free access to the commons of health care, social security payments, state pensions. It will prevent terrorists from destroying the common right to move around in safety. And this will all be achieved with a state-run identity card system.

Unfortunately, the only property that all systems have in common is that they will fail. And the bigger the system - 60 million plus data records in a compulsory ID 
card database of the UK population — the greater the opportunity of failure. Databases pick up errors and then build data error upon error, and like all systems they degrade over time: entropy. The UK Driver and Vehicle Licensing Agency (DVLA) in Swansea, for instance, admitted in 2006 that a third of entries in their database contained at least one error, and that the proportion was getting worse.

However scrupulous operators might be, errors leak and take on a life of their own. They are sampled (farmed) by other databases: errors, even when corrected in the original database, live on elsewhere. The American Psychological Association (Squires 1988) says that omnipresent computer screens distract, and cause confusion and errors of judgement: they call it the 'glass-cockpit syndrome.' This syndrome has two effects: end users rely entirely on the system without exercising any judgement or discretion; and the ensuing information overload results in users ignoring many pieces of (sometimes very important) information. All databases throw up false-positives, where innocents are identified as guilty. Granted the percentage of errors is small, but when a person's very existence can be brought into question, each single error is one too many.

In the UK the population is being told that the government's ID project will be different. The project is one of the biggest computer systems envisaged - far more complex than the failing National Health Service system. Apparently iris scans, fingerprints, face-recognition software will all work perfectly, be amazingly cheap to implement - and all foolproof. It must be true, as the government has been told this by those selling the technology. Baroness Anelay of St Johns, with a group of parliamentarians, was once given a demonstration of a facial recognition system. It failed; indeed the system subsequently crashed, twice. The reason? The baroness was told her face was "too bland."

Fingerprints too have proved problematic. The Chaos Computer Club (CCC), the long-standing German hackers' club, has shown how to capture fingerprints and transfer them onto a foil, and then demonstrated how it could be worn to beat biometric readers across Germany. To add insult to injury CCC has published a fingerprint of the German Interior Minister, Wolfgang Schauble, a vocal supporter of biometrics.

But there's always the DNA database, there to catch criminals. Television series trumpet the myth of forensic investigators collecting biological material from the scene of crime, comparing DNA samples with a database, and out pops the criminal's name: end of story! Nothing is that simple. Felons will vacuum up DNA from football crowds, collect cigarette-ends, hospital detritus, and randomly scatter samples when perpetrating crime. The number of false positives will go through the roof.

Nevertheless, according to the rhetoric, an ID card, one central point of reference, will be so much more efficient and beneficial than us having to produce driving licenses, bills for electricity or local taxes, and so on whenever we need to prove our identity when undertaking legal/commercial transactions. Its proponents fail to see that if any of these documents is erroneous, then we just don't use the one with, say, a mistake in the address. With the ID card, we won't have the choice. Even if the card is not compulsory, all financial systems will converge on it, and anyone without a card faces great cost and inconvenience.

However, and despite numerous reports of Smart Cards being hacked, the ID card itself isn't the real problem: it's the ID register. There will be errors, and they won't 
just happen by accident. It's not unimaginable that workers on the ID register will be corrupted, threatened or blackmailed into creating perfectly legal ID cards for international terrorists and criminals. Then the ID card, far from eliminating problems, will be a one-stop shop for identity fraud; foreign terrorists, illegal immigrants will be waived past all immigration checks.

At a Ditchley Park conference on "Combating Organized Crime" in January 2008, a persistent warning from the law enforcement authorities was that criminal gangs had placed "sleepers" in financial sector companies, and they were just waiting for 'the one big hit.' The perpetrators of $80 \%$ of all computer security lapses are not hackers, but employees. Cryptographic systems don't help if the criminal has been given the keys to the kingdom. Why should the UK ID centre be immune, especially when there will be nearly 300 government departments and who knows how many tens of thousands of companies logging in. And just as bad, the register will be the Number One target for every hacker on the planet: cracking it will be the Olympic Gold Medal of hacking.

However, even this dreadful scenario pales into insignificance against the ultimate identity theft. Each record on the register will eventually take on a legal status. In a short time, all other proofs of identity will refer back to the one 'true' record. If an entry in the register is wrong - and fallible human hands will at some stage have to handle your personal information - then its reappearance in all other databases will be wrong too. Given the propensity of officialdom to trust the details on their computer screen, rather than the person in front of them, we will have to conform to our entry in the register - or become a non-person.

In effect, our identities won't reside in the living flesh and blood of us, but in that one true legally legitimated record in the register. Each identity will be digitally enclosed, separated from the person, and turned into property - to be owned by others. All our property and money will de facto belong to the corresponding records in the register, and rights to that record will no longer be ours to decide. It no longer belongs to us. Each of us has legal access to our property only with the permission of the register, and we must apply with everyone else who has been give rights to access our assets. Money will be transferred from our bank accounts whenever it is told to do so by the register - and the tax authorities will be first in line.

Paradoxically, we only agreed to register to protect ourselves from 'identity theft,' and instead we find ourselves victim of the ultimate identity theft — the total loss of control over our identities. Somebody other than us owns our identity, and they reserve the rights to turn it into property and to monetize it. There's another word for this - slavery!

Welcome to the Brave New World, a world that has lost all sense of 'fair play, "a world of rapacious, state-aided "privatization"” of enclosed identity: the ultimate identity theft.

\section{References}

Boyle J. The second enclosure movement and the construction of the public domain. Law and Contemporary Problems. Vol. 66:33; 2003. Winter/Spring 2003.

Doctorow C. Warhol is turning in his grave, The Guardian, London; 2007. Tuesday November 13. 
Dove A. When science rides the MTA. J Clin Invest.110:425-427; 2002.

Hardin G. The tragedy of the commons. SCIENCE, 1968; Dec. 13.

Heller MA, Eisenberg RS. Can patents deter innovation? The anticommons in biomedical research, SCIENCE, 1998; May 1.

Mason MJ. The pirate's dilemma: how youth culture is reinventing capitalism. London: Allen Lane; 2008

Mercer I, Kinsella S. Do patents and copyrights undermine private property?', Insight Magazine; 2001. 21 May.

Minogue K. Politics: a very short introduction. USA: Oxford University Press; 1995.

Orwell G. 1984, Penguin Classics. London (new edition 2004.);1949.

Smith A. The Wealth of Nations, Penguin Classics, London (new edition 1982.); 1776.

Squires S. The 'Glass Cockpit' Syndrome: How High Technology and Information Overloads Contribute to Fatal Mistakes. In The Washington Post, October 11; 1988.

Stefik M, Stefik B. Breakthrough: stories and strategies of radical innovation. Cambridge Mass: MIT; 2006. p. 28.

Vidal J. McLibel: burger culture on trial. London: Pan Books; 1997.

Wald P. What's in a Cell?: John Moore's Spleen and the Language of Bioslavery', New Literary History Volume 36, Number 2, Spring; 2005. p. 205-225.

WIPO Bioethics and Patent law: the cases of Moore and the Hagahai People', WIPO Magazine, Issue 5, September; 2006. 